九州大学学術情報リポジトリ

Kyushu University Institutional Repository

Population Ecology of the Japanese Field Vole (Microtus montebelli) in Kyushu : III. Contagious Distribution in the Growth Phase

Arai, Shusei

Zoological Laboratory, Faculty of Agriculture, Kyushu University

Shiraishi, Satoshi

Zoological Laboratory, Faculty of Agriculture, Kyushu University

Uchida, Teruaki

Zoological Laboratory, Faculty of Agriculture, Kyushu University

https://doi.org/10.5109/23767

出版情報 : 九州大学大学院農学研究院紀要. 27 (3/4), pp.143-150, 1983-02. Kyushu University バージョン：

権利関係 : 


\title{
Population Ecology of the Japanese Field Vole (Microtus montebelli) in Kyushu

\author{
III. Contagious Distribution in the Growth Phase
}

\section{Shusei Arai, Satoshi Shiraishi and Teru Aki Uchida}

Zoological Laboratory, Faculty of Agriculture, Kyushu University 46-06, Fukuoka 812

(Received September 2, 1982)

\begin{abstract}
The distributional pattern appearing with the population change of Microtus montebelli was examined in a very small restricted area of Mt. Hitome in the northern Kyushu. In native grassland, the places damaged intensely by the vole exhibited a patchy distribution bounded clearly by the uninjured area. In a grid established on the young plantation, the distribution of the points of capture was contagious and uneven during the growth phase (from December 1975 to April 1976), and the contagion was proved by Morisita's I $\delta$-index. Afterwards (from June 1976 of the peak phase to October 1976 of the beginning of the declining phase), the points showed a tendency to spread over the greater part except the part of the shrubs growing at the northwest of the grid. In the growing population, the vole was strongly sedentary, and there appeared frequently males with a placid temper. Accordingly, it seems likely that less agonistic behavior and reduction of the home range in the growing population result in the contagious distribution with the unusual high population density. Also, the population with the contagion of the vole's own property, the so-called "Great families", appeared to consist of one to several families.
\end{abstract}

\section{INTRODUCTION}

It has been well known that the Japanese field vole, Microtus montebelli, is captured in an irregular catch-pattern even though the physiognomy in vegetation is much the same one another (Tokuda, 1954, 1959; Kaneko, 1973), and that the vole lives gregariously and shows a contagious distribution in their habitat (Tokuda, 1954; Mochizuki, 1962). Moreover, Tokuda (1954) suggested that such a gregariousness of the vole often caused outbreaks, and Kaneko (1973) discussed the factors causing the vole's uneven distribution. The contagious distribution has been reported in Microtus arvalis inhabiting Europe, too (Frank, 1957; Corbet and Southern, 1977). These authors, however, only referred to the contagion or uneven distribution as a phenomenon.

We have been investigating the population ecology of the vole at Mt. Hitome in the northern Kyushu since December 1975. The population fluctuation of the vole consisted of three phases, i.e. the growth phase from December 1975 to April 1976, peak phase in June 1976 and declining phase in and after August 1976 (Arai and Shiraishi, 1982). We produce here statistical evidence 
for the contagious and uneven distribution of the vole, which appeared only in the growth phase, in a very small restricted area.

\section{STUDY AREA AND METHODS}

The whole area around the top of Mt. Hitome (altitude of $1.287 \mathrm{~m}$ ) locating on the border between Kumamoto and Ōita Prefecture is widely covered with various grasses and there is a small-scale young plantation (Chamaecyparis obtusa and Larix leptolepis) adjoining to the native grassland in a part of the southwest slope. The young plantation and a part of the native grassland were chosen as the study area, and a live-trapping grid with an area of 0.49 hectare $(70 \mathrm{~m} \times 70 \mathrm{~m})$ was established at the northern end of the plantation in order to analyse the vole's distribution (Fig. 1). Shrubs such as Hydrangea paniculata, Pieris japonica and others grew in the northwest part of the grid.

One hundred and ninety-six Sherman traps were set with five meters' trap spacing on a grid. The mark-and-recapture method was applied for three days. Presence or absence of the vole's signs and degree of damage due to its gnawing, also, were examined in the study area. We dealt mainly with the results obtained during the growth phase, together with the supplemental data from the peak phase to the beginning of the declining phase (October 1976).

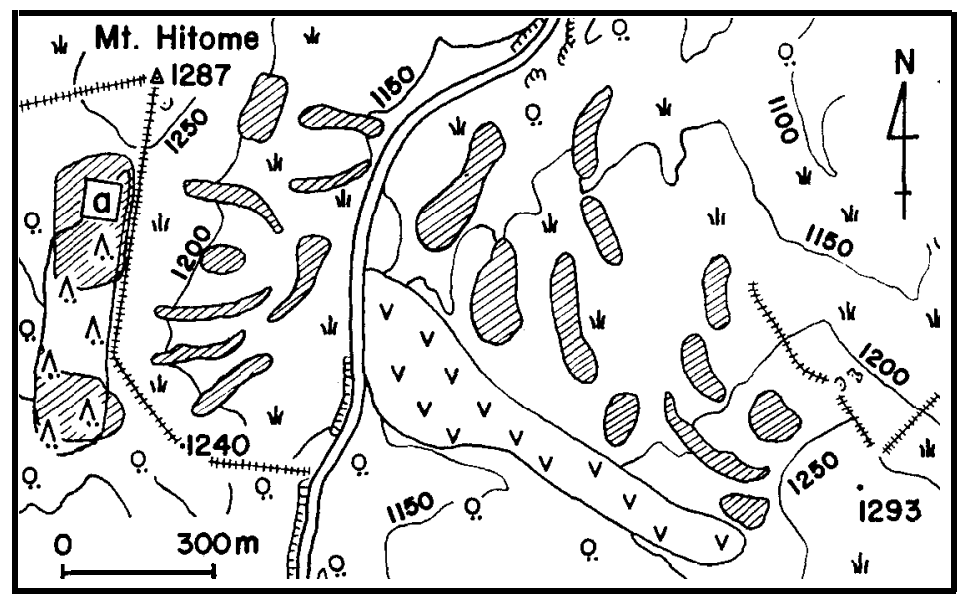

Fig. 1. Map showing the location of the study area for Microtus montebelli at Mt. Hitome from December 1975 to October 1976. a, live-trapping grid; 1 . damaged place;.. , needle-leaved tree (young plantation); Q., broad-leaved tree; $\boldsymbol{l}_{\ell}$, native grassland; V, pastureland;*, dike; $=$ road. 


\section{RESULTS}

\section{Aspect of damage by the vole}

As the vole had been poisoned with a rodenticide (zinc phosphide) in late November 1975 by Kyushu Electric Power Co., Inc. to which this land belongs, the vole's density before the poisoning operation is unknown. The damage, however, had already spread all over the native grassland by the time of our first survey early in December 1975. In the heavily damaged places where we could find accumulations of numerous droppings, networks of the run ways, many burrow entrances and cuttings by the voles, there was a patchy distribution clearly distinguished from the uninjured area (Fig. 1).

\section{Distribution of the points of capture on the grid}

The points of capture and the number of the captured vole $(\mathrm{N})$ on the grid in each investigation-month are shown in Fig. 2. Frequency of capture at a single point is presented in total regardless of individuals. In the growth phase, the points of capture were mainly distributed in the central and northwest parts of the grid in December 1975, and in the central and the southwest parts in February 1976, and from the center to the southwest in April 1976, and consequently exhibited a tendency to be contagiously and unevenly distributed (Fig. 2A-2C). To clarify the contagious tendency, Morisita's
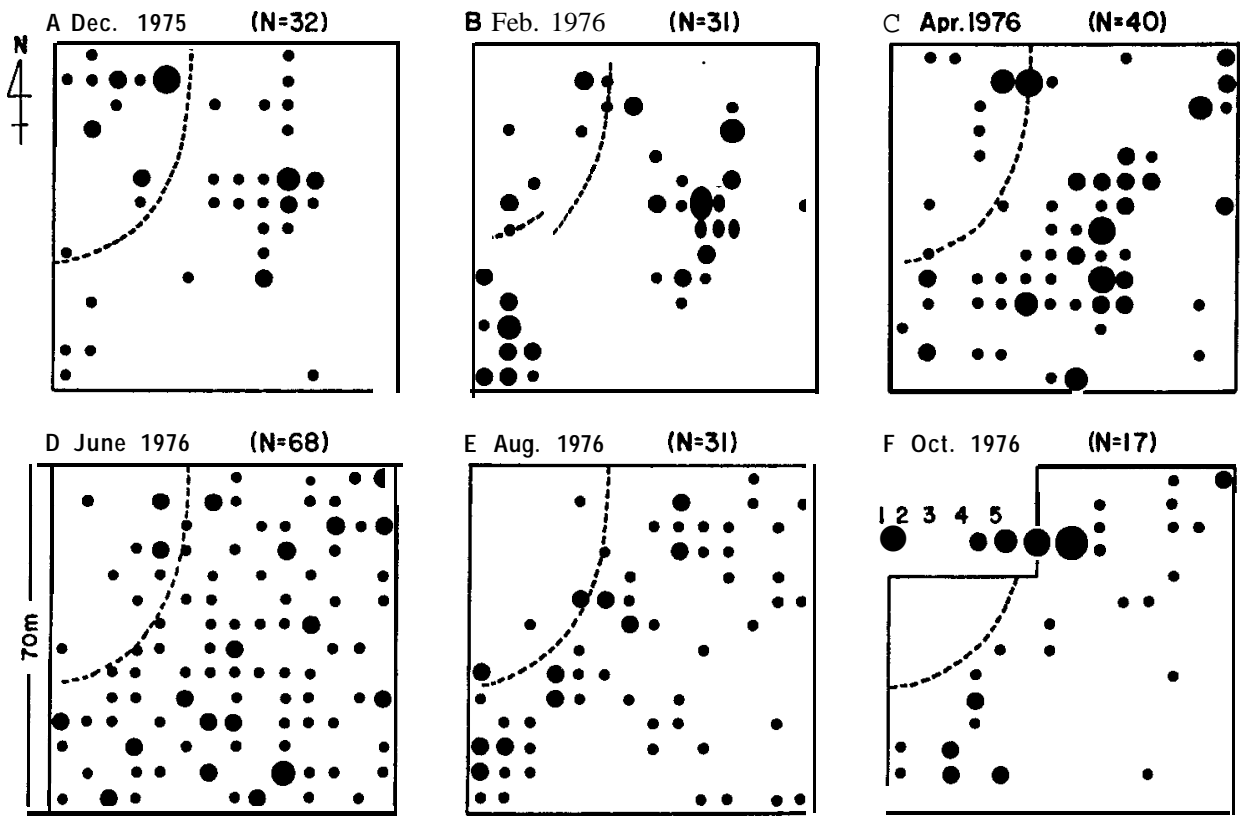

Fig. 2. Distribution of captured points for Microtus montebelli in the grid from December 1975 to October 1976. Shrubs grow in the northwest part bounded by broken line. $\mathrm{N}$ is the captured number of the voles. 
Table 1. Contagious distribution of Microtus montebelli estimated by Morisita's Id-index from December 1975 to October 1976

\begin{tabular}{|c|c|c|c|c|c|c|}
\hline \multirow{2}{*}{ Item } & \multirow{2}{*}{$\frac{1975}{\text { Dec. }}$} & \multicolumn{5}{|c|}{1976} \\
\hline & & Feb. & Apr. & June & Aug. & Oct. \\
\hline $\begin{array}{l}I \delta \\
F\end{array}$ & $\begin{array}{l}2.50 \\
1.35\end{array}$ & $\begin{array}{l}3.32 \\
1.73\end{array}$ & $\begin{array}{l}2.20 \\
1.55\end{array}$ & $\begin{array}{l}0.64 \\
0.80\end{array}$ & 1.01 & $\begin{array}{l}1.86 \\
1.14\end{array}$ \\
\hline
\end{tabular}

$$
I \delta=q \times \frac{\sum_{i=1}^{q} x_{i}\left(x_{i}-1\right)}{T(T-1)} \quad F=\frac{I \delta(T-1)+q-T}{q-1}
$$

$\boldsymbol{q}$, total number of quadrats; $\boldsymbol{x}_{\boldsymbol{i}}$, number of individuals trapped in each of the captured points $(i=1,2,3, \cdots \cdots, q) ; T$, total number of individuals in the total quadrats.
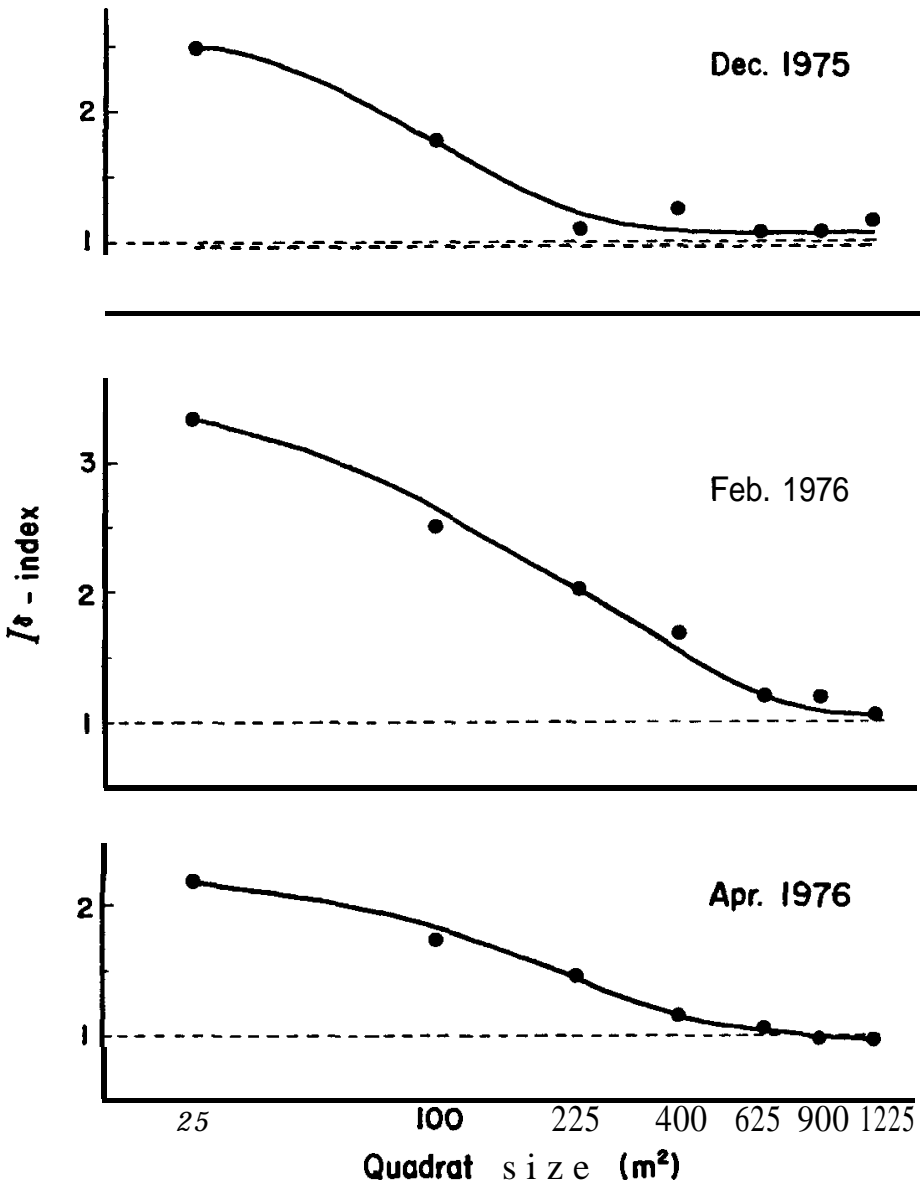

Fig. 3. Changes in Morisita's $\mathbf{I} \delta$-index for Microtus montebelli in the grid from December 1975 to April 1976. 
I $\delta$-index (Morisita, 1959) was applied, together with the significance tested for the value of $F$ by Ito and Murai (1978). As the result, the contagion was confirmed and significant $(p<O$. 01) in each of them, being especially remarkable in February 1976 (Table 1). The distributional pattern during this phase was contagious with small gregariousness (Fig. 3).

In the peak phase (June 1976), the points of capture spread over the greater part except a part of the shrubs growing in the northwest part of the grid (Fig. 2D); therefore, a contagion was not confirmed by the $I \delta$-index (Table 1). In August when the population began to decline rapidly, most points of capture were obtained from the southwest to the northeast part of the grid (Fig. 2E), but a contagion was not found (Table 1). Although the distribution of points of capture in October showed a tendency resembling that of August, the points scattered with a blank in the central part of the grid(Fig. 2F); in this case, a week contagion was recognized by the Z\&index, not being significant at the $1 \%$ level (Table 1). The central part, devoid of points of capture, corresponded to the place with the contagiously high density in the growth phase.

\section{Degree of dispersion out of the grid}

In order to examine the dispersion degree of the marked and released voles, 14 snap traps were set on each side about 20 meters away from the margin of the grid for only one night per one census (four times from April to October 1976), so as to avoid disturbance against the recapture as much as possible. As the result, one marked male and female each was recaptured in August south and east outside the grid, respectively. Also, snap trapping was carried out several times in the broad-leaved forest about 50 meters toward the west of the grid, we could not catch any of the voles and did not find droppings and run ways either. Although another trial was also made periodically on the native grassland about 300 meters east from the grid, no marked vole could be obtained. To sum up, the vole hardly disperses and is strongly sedentary.

\section{DISCUSSION}

The uneven distribution of the vole in the growth phase results from concentrations at certain places. Such an unusual high density in the growing population of Microtus has been recognized also from experiments with an enclosed population of M. pinetorum (Gentry, 1968), M. pennsylvanicus and M.ochrogaster (Krebs et al., 1969). These voles, however, solve disadvantages suffering from their much higher population densities by migration and dispersion (Gentry, 1968; Myers and Krebs, 1971; Krebs et al., 1973). Also, it has been suggested or concluded that adult males limit the recruitment of juvenile and subadult males into the breeding population of $M$. arvalis (Stein, 1953; Frank, 1957), M. agrestis and Clethrionomys glareolus (Chitty and Phipps, 1966), M. townsendii (Boonstra, 1978) and M. montanus (Jannett, 1991). In M. pennsyluanicus (Turner and Iverson, 1973) and M. townsendii (Krebs et al., 1977; Gipps et al., 
1981), aggressive individuals appearing in the growing population cause its decline by inducing death or dispersal through their aggressive interaction.

In the present study, the vole scarcely dispersed out of the grid, and there appeared frequently males with a placid temper and few individuals injured through intraspecific competition in the growing population (Arai and Shiraishi, 1982). It seems likely that less agonistic behavior in the growing population and the reduction of the home range due to an increase of the population density (Arai and Shiraishi, 1982) result from the sedentary nature of the vole, and consequently in the contagious distribution with the unusual high population density. As designated as "Great families" in $M$. arvalis (Frank, 1957), in $M$. montebelli also the population with the contagious occurrence appears to consist of from one to several families. In fact, a few adult voles were captured in a nest at the time when plaster was poured into it, and furthermore the voles kept under a high density in captivity were hardly agonistic (unpublished).

Kaneko (1973) tried to attribute the uneven distribution of the vole to interspecific (intergeneric) competition between Microtus montcbelli and Apodemus speciosus, which was impossible. A. speciosus and Eothenomys smithi inhabiting the broad-leaved forest adjacent to the grid entered mainly the shrubbery place of the grid during the period from April to October 1976 in which the peak phase of the vole population was involved and the contagious distribution began to breakdown. Also neither A. speciosus nor E. smithi was captured in the grid in December 1975 and February 1976, when the vole population density was rather low and the distribution was contagious (unpublished). Thus, these phenomena mean that the contagious (uneven) distribution of the vole is independent of interspecific agonistic behavior among the sympatric species; the invasion seems to relate closely with an increase of the population density of both the species in the broad-leaved forest and of the crown density of the shrubs on the grid. Other factors may be involved in the contagion of the voles, such as suitableness of environmental topography, amount of predators and so on, but there was no persuasion in such factors.

Judging from the above, it is concluded that the contagious distribution (Great families) of the vole originates from its own gregarious and sedentary nature. The contagion of the vole clearly plays an important role in the outbreak. On the other hand, the vole's population density in the grid crashed rapidly after the peak phase. This fact may produce evidence that the contagion exerts bad influences, e.g., aggravation of the habitat and deterioration of the gene pool, upon the vole population. To prove the contagious property of the vole, analyses of the family structure and the social behavior remain unsolved.

\section{ACKNOWLEDGEMENTS}

We are greatly indebted to Professor E. W. Jameson, Jr., University of California, for comments on the manuscript. We are very grateful to the staff and former graduate students of Zoological Laboratory, Kyushu University, 
who help us in this study, and also to Kyushu Electric Power Co., Inc., for kind help in lending us the study area. This work was supported by Grantin-Aid for Scientific Research from the Ministry of Education, Science and Culture of Japan (Nos. 056159, 156095 and 256110).

\section{REFERENCES}

Arai, S. and S. Shiraishi 1982 Population ecology of the Japanese field vole (Microtus montebelli) in Kyushu I. Changes in population size and home range. Sci. Bull. Fac. Agr., Kyushu Univ., 36: 89-59 (in Japanese with English summary)

Boonstra, R. 1978 Effect of adult Townsend voles (Microtus townsendii) on survival of young. Ecology, 59: 242-248

Chitty, D. and E. Phipps 1966 Seasonal changes in survival in mixed population of two species of vole. J. Anim. Ecol., 35: 313-331

Corbet, G. B. and H. N. Southern 1977 The Handbook of British Mammals. Blackwell, Oxford, pp. 151-265

Frank, F. 1957 The causality of microtine cycles in Germany. J.Wildlife Manag., 21: 113121

Gentry, J. B. 1968 Dynamics of an enclosed population of pine mice, Microtus pinetorum. Res. Popul. Ecol., 5: 21-30

Gipps, J.H. W., M. J. Taitt, C. J. Krebs and Z. Dundjerski 1981 Male aggression and the population dynamics of the vole, Microtus townsendii. Can. J. Zool., 59: 147-157

Ito, Y. and M. Murai 1978 Methodology of Animal Ecology I. Kokin-Shoin, Tokyo, pp. 5156 (in Japanese)

Jannett, F. J., Jr. 1981 Sex ratios in high-density population of the montane vole, Microtus montanus, and behavior of territorial males. Behav. Ecol. Sociobiol., 8: 297-307

Kaneko, Y. 1973 Geographically small scale distribution of Japanese meadow mice, Microtus montebelli-Distributional pattern of small rodents in the alluvial area of Kyoto City-. Mem. Fac.Educ., Kagawa Univ., II, (224) : 1-13 (in Japanese with English abstract)

Krebs, C. J., M. S. Gaines, B. L. Keller, J. H. Myers and R. H. Tamarin 1973 Population cycles in small rodents. Science, 179: 35-41

Krebs, C. J., Z. T. Halpin and J. N. M. Smith 1977 Aggression, testosterone and the spring decline in population of the vole, Microtus townsendii. Can. J. Zool., 55: 430-437

Krebs, C. J., B. L. Keller and R. H. Tamarin 1969 Microtus population biology: demographic changes in fluctuating population of $M$. ochrogaster and $\mathbf{M}$. pennsylvanicus in southern Indiana. Ecology, 50: 587-607

Morisita, M. 1959 Measuring of the dispersion of individuals and analysis of the distributional patterns. Mem. Fac. Sci., Kyushu Univ., Ser. E (Biol.), 2: 215-235

Mochizuki, M. 1962 Ecological studies on the paddy mouse, Apodemus speciosus and the vole, Microtus montebelli, in cultivated fields. Occ. Pap. Toyama Agr. Exp. St., (4) : l-135 (in Japanese)

Myers, J. H. and C. J. Krebs 1971 Genetic, behavioral, and reproductive attributes of dispersing field voles Microtus pennsylvanicus and Microtus ochrogaster. Ecol. Monog., 41: $53-78$

Stein, G. H. W. 1953 Über das Zahlenverhältnis der Geschlechter bei der Feldmaus, Microtus arvalis. Zool. Jahrb. Syst., 82: 137-156

Tokuda, M. 1954 Several problems on ecology of voles and field mice. In "Voles and Field Mice and Their Controi", ed. by K. Misaka, The Japan Society for the Promotion of Science, Tokyo, pp. 41-63 (in Japanese) 
Tokuda, M. 1959 Japanese field vole, Microtus montebelli, of Mt. Ibuki-Actual condition of the outbreak and its factors. Hoppó Ringyó, (126): 5-10 (in Japanese)

Turner, B. N. and S. L. Iverson 1973 The annual cycle of aggression in male Microtus pennsyluanicus, and its relation to population parameters. Ecology, 54: 976-981 